wurde, das sich selbst als dänisch bezeichnete. Das Schreiben und Einsenden von dänischen Aufsätzen wird zu einer Art Praktizieren des Dänischen, zu dem die Zeitschrift Methoden liefert. Die dänischen Kinder in Nordschleswig waren die Vertreter des schleswigschen Kindes (det sønderjyske barn). Illustreret Børneblad for Nordslesvig zeigt durch seinen Inhalt, womit sich die dänischen Kinder in Nordschleswig beschäftigen. Diese Themen findet man auch in den Aufsätzen der Kinder Obwohl die Zeitschrift eine Rolle als Konstrukteur einer Vorstellung des schleswigschen Kindes spielt, vertritt diese Vorstellung gleichzeitig eine Norm, die sich in den Aufsätzen der Kinder wiederfinden lassen. So spielen die Kinder selbst eine wichtige Rolle in der Erschaffung des Begriffs von "det sønderjyske barn".

\section{Sydslesvigske børns ferierejser til Danmark 1949 til 1974}

\section{Et blik på en snart hundredårig tradition.}

\section{Af Marianne Brink Asvig Iversen}

Siden 1919 er tusindvis af sydslesvigske børn sendt på sommerophold i Danmark, men hidtil er der ikke foretaget nogen systematisk undersøgelse af disse feriers betydning for børn og værtsforældre. I 2016 iværksatte jeg derfor en spørgeskemaundersøgelse, der skulle afdække, dels hvordan ferieopholdene blev oplevet af de implicerede, dels hvilke spor de havde sat sig på længere sigt. I denne artikel fremlægges resultaterne.

\section{Indledning}

I snart 100 år har sydslesvigske børn fået en kulturel oplevelse i Danmark som feriebørn hos danske familier. Ordningen begyndte efter Første Verdenskrig, hvor nøden var stor i den sønderjyske befolkning. Danskerne på den anden side af Kongeåen stod klar til at hjælpe, og derfor blev nødlidende børn fra Syd- og Nordslesvig sendt afsted med hjuldamperen Ægir fra Flensborg og Sønderborg. ${ }^{1}$

Arbejdet med feriebørnene blev i 1919 organiseret af Komiteen for Sønderjyske børns Landophold i samarbejde med De danske Menighedsplejer. Efter grænseændringen i 1920 førte komiteen arbejdet videre alene og sendte - senere under navnet Komiteen for slesvigske Børns Ferierejser - de efterfølgende mange år tusinder af børn på ferie i Danmark. Det eneste år, hvor ferierejserne ikke kunne gennemføres, var i 1940, hvor Danmark som bekendt blev besat af Tyskland. Arbejdet var blevet hæmmet allerede fra midten af 1930'erne under Tysklands nazistiske styre, men desuagtet fortsatte feriebørnene med at komme til Danmark. ${ }^{2}$ Da krigen sluttede i 1945, lykkedes det sidst i august at sende cirka 500 børn afsted, men de følgende år steg tallet voldsomt. Nøden var igen stor i Sydslesvig, og danskerne ville endnu engang gerne hjælpe. ${ }^{3}$ Sammenlagt blev knap 27.900 feriebørn sendt til Danmark i årene 1947 til 1949. ${ }^{4}$

Den hidtidige forskning i de sydslesvigske børns ferierejser til Danmark er meget begrænset. Emnet er kort omtalt af henholdsvis Martin 
Klatt og René Rasmussen i to afsnit af Sydslesvigs danske historie, og feriebørnene er ligeledes behandlet i en artikel af Hanne Midskov og Per Johannsen i Grænseforeningens årbog fra 2004. Her giver de to forfattere et historisk overblik over feriebørnsordningens første 85 år og giver nogle eksempler på feriebørn og værter, som fortæller deres egne historier. Da det imidlertid er vanskeligt at afgøre, hvor repræsentative disse fortællinger er, har jeg valgt at foretage en spørgeskemaundersøgelse og ad den vej indhente systematiserede oplysninger om feriebørnenes og deres værters erfaringer. Spørgeskemaet blev sendt ud til tidligere feriebørn, som jeg fik kontakt med over de sociale medier og igennem radiointerviews og artikler i Flensborg Avis. Jeg sendte 141 skemaer ud og fik 103 besvarelser retur. 19 kom fra tidligere værtsfamilier, 65 fra tidligere feriebørn med erfaringer fra den omtrentlige periode 1949 til 1960 og de resterende 19 fra respondenter, der havde været på ferieophold i årene omkring 1960 til 1974. I forhold til især værtsfamilierne og feriebørnene fra perioden 1960 til 1974, kan det diskuteres, hvor stor repræsentativitet, man tør tillægge så relativt få besvarelser. 19 spørgeskemaer fra hver af de to grupper udgør næppe et kvalificeret udsnit af feriebørn og værter for den valgte periode. Når hovedparten af besvarelserne vedrører årene 1949 til 1960, tyder det på, at den ældre generation af feriebørn har haft et større ønske om at dele deres erindringer, end det har været tilfældet for den yngre generation. For værtsfamiliernes vedkommende lever en stor del af værtsmødrene og -fædrene ikke længere, så det har primært været deres børn, altså de sydslesvigske feriebørns feriesøskende, som har udfyldt skemaerne. Antageligt har disse ikke haft en lige så stor interesse $\mathrm{i}$ at udfylde spørgeskemaet, som man ville kunne have forventet af datidens værtsforældre, og det har påvirket svarmængden. Dette skal således tages med i betragtning ved læsning af nedenstående.

Et yderligere forbehold skal knyttes til spørgeskemaerne som kildemateriale, idet de indeholdt spørgsmål af både kvantitativ og kvalitativ art. De kvalitative spørgsmål gav deltagerne mulighed for at beskrive elementer af ferierejserne, som ikke kan måles kvantitativt, og de var dermed med til at give en bredere forståelse af ferierejserne. Det er imidlertid problematisk, at respondenterne har skullet genkalde sig tidligere oplevelser så mange år efter, at de har fundet sted. Mange vil primært huske de gode oplevelser, der tenderer til at overskygge de dårlige, når man får tingene på afstand. Andre vil formentlig - bevidst eller ubevidst - have underkommunikeret erindrede negative oplevelser til fordel for de positive aspekter.
Med disse forbehold in mente er de indkomne besvarelser lagt til grund for den følgende undersøgelse af, hvordan de pågældende feriebørn og værtsfamilier oplevede ferieopholdene, hvad de fik ud af besøgene, og hvad ferierejserne betød for børnene på kort og på lang sigt.

\section{Så kører toget}

I de første år efter Anden Verdenskrig led Sydslesvig under mangel på stort set alt, og det hjalp ikke på situationen, at der skulle findes boliger, mad og arbejde til cirka 300.000 flygtninge, som i krigens sidste tid havde søgt tilflugt i Sydslesvig fra især Østpreussen. ${ }^{5}$

De børn, som i disse vanskelige tider blev tilbudt at komme på ferierejser i Danmark, kom fra de danske skoler og børnehaver i Sydslesvig. Tilgangen til især skolerne var i de første efterkrigsår meget høj, og antallet af danske skoler steg fra ni i maj 1945 til 80 i 1950. Elevtallet var da nået op på 13.867. ${ }^{6}$ Denne udvikling afspejlede en eksplosiv tilgang til det danske mindretal af hidtil tysksindede, og mange af de danske skolers elever kom således fra oprindeligt tyske hjem. Det betød, at de som regel var tysksprogede og uden noget særligt forkundskab til danske forhold og dansk kultur. I de danske skoler var der altså nok at tage fat på, men ferierejserne var et godt supplement. En sommerferie i Danmark forbedrede sprogfærdighederne, så børnene efterfølgende fik et større udbytte af skolens undervisning, og det gav dem en førstehåndsoplevelse af dansk kultur, som kunne virke befordrende på deres danske identitet, hvad enten den allerede var grundlagt i hjemmet eller først nu skulle udvikles. Ferierejserne indgik således i et større nationalpolitisk projekt, der skulle udbrede danskheden blandt sydslesvigerne, men det var et voksenperspektiv. For børnene var rejserne til Danmark et ferieophold, der gav andre erfaringer end de hjemlige. Hvordan rejserne kunne opleves, giver spørgeskemaerne et billede på.

Cirka $60 \%$ af feriebørnene kom det samme sted hen år efter år, ikke kun rent geografisk, men de kom også til den samme familie. I spørgeskemaerne rettede en del af dem, som havde været flere forskellige steder som feriebarn, overvejende deres fokus på den ene familie, som de var hos i en årrække, og ikke på de værtsfamilier, som de kun besøgte få gange. Der gives ikke nogle entydige svar på, hvorfor børnene skiftede værtsfamilier; svarene var meget individuelle, og nogle valgte ikke at skrive hvorfor. Det kan dog formodes, at nogle børn har skiftet plads, fordi familien og barnet ikke passede godt sammen. I andre til- 
fælde har værtsfamilien formodentlig ikke haft mulighed for fortsat at modtage feriebarnet af praktiske årsager. Selvom der ikke kan gives et overordnet svar på, hvorfor feriebørnene skiftede familie, så kan det dog konstateres, at noget er blevet udeladt. Om opholdene hos de familier, som feriebørnene ikke vendte tilbage til, var gode eller dårlige, ved vi således ikke, men må konstatere, at historierne om disse ophold er gået tabt i forhold til denne undersøgelse.

Den mest gængse forklaring på, at de sydslesvigske børn sidst i 1940'erne og først i 1950'erne blev sendt på ferierejse i Danmark, var, at de trængte til en ordentlig ernæring. Nogle af dem havde mange søskende, så det blev derfor også en form for aflastning for deres forældre, der dermed ikke havde så mange munde at mætte. Flere respondenter berettede også, at de skulle væk fra de grimme krigsoplevelser. En tredje meget brugt forklaring på ferieopholdet var behovet for at indlære det danske sprog og den danske kultur. Der kunne altså være flere grunde til, at rigtigt mange sydslesvigske forældre sendte deres børn til Danmark i slutningen af 1940'erne og starten af 1950'erne. Eksempelvis lå antallet af feriebørn på cirka 10.000 i 1949 for dog at være faldet til 5.173 i 1954 .

Feriebørnene, som var afsted i perioden fra sidst i 1950'erne til midt i 1970'erne, havde ikke på samme måde behov for at komme til Danmark på grund af materiel nød, men de fortsatte en tradition, som havde eksisteret i mange sydslesvigske familier i flere år. ${ }^{8}$ Antallet af feriebørn i denne periode lå på cirka 2.000 årligt, ${ }^{9}$ men dertil kom, at flere var begyndt selv at besøge deres værtsfamilier uden om feriebørnsordningen.

For de fleste sydslesvigske feriebørns vedkommende startede turen til Danmark imidlertid på Flensborg Banegård. Alle feriebørn fik på banegården et skilt om halsen med navnet på både forældre og værtsforældre, så rejselederne vidste, hvor børnene hver især skulle af. Rejselederne fulgte nemlig børnene på både udrejsen og hjemrejsen, hjalp dem igennem den tyske og danske grænsekontrol og sørgede for, at de kom frem til rette sted. På banegården i Flensborg skulle rejselederne desuden sikre sig, at børn og paslister stemte overens, så alle kunne krydse grænsen uden problemer. ${ }^{10}$

Det har været en anseelig logistisk opgave at få alle disse feriebørn sendt afsted til Danmark, og det har krævet mange frivillige hænder og meget forarbejde. Men for børnenes forældre var opgaven slut, når børnene var afleveret til rejselederne. De var nemlig forment adgang til

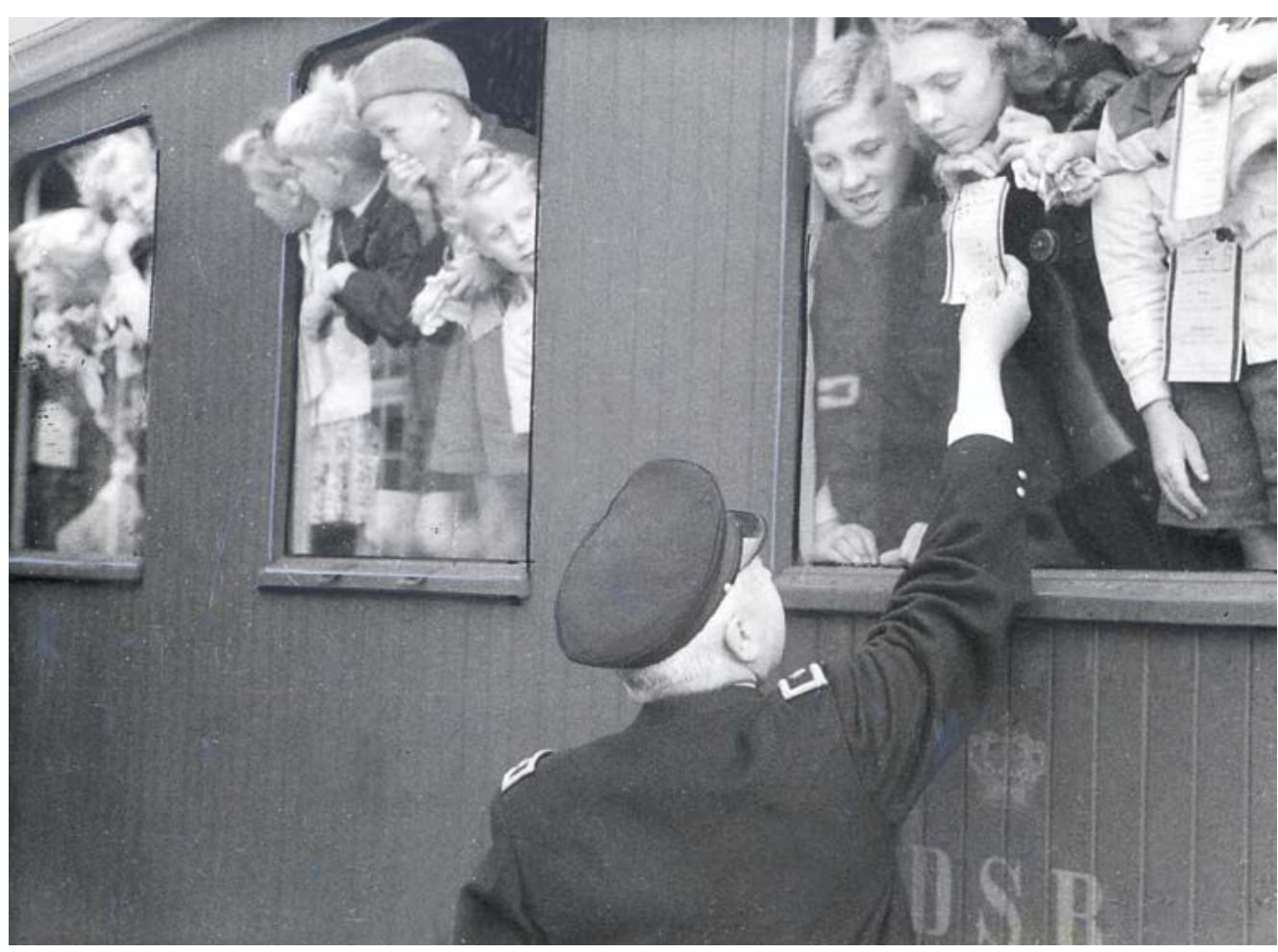

Klar til afgang på Flensborg Banegård sommeren 1949. En pige viser togkontrolløren sin rejseseddel, som hun ligesom de andre børn har hængt om halsen. Kilde: Arkivet ved Dansk Centralbibliotek for Sydslesvig, ukendt fotograf.

perronen, hvorfra togene afgik, for dels var der ikke plads til dem, dels var det ikke tilladt på grund af tolden. ${ }^{11}$

Flere af de tidligere feriebørn, der har deltaget i undersøgelsen, mindes, hvordan de på banegården i Flensborg sang danske sange som Grundtvigs "Den signede dag med fryd vi ser", men kun det sidste vers: "Så rejser vi til vort fædreland, der ligger ej dag i dvale...". Fra selve togrejsen mindes nogle, at stemningen var høj, og at de også her sang danske sange, men for andre blev turen meget lang, især hvis de skulle til Sjælland eller Nordjylland. Sådanne erindringer er meddelt af nogle af de feriebørn, som var afsted i 1940'erne og 1950'erne, hvor turen foregik med datidens "bumletog", der stoppede ved de mange små stationer. Et ophold på en togstation var imidlertid ikke kun af det 
onde; her oplevede nogle af børnene nemlig at stifte bekendtskab med ispinden, som de hidtil ikke havde kendt til.

Feriebørnene fra 1960'erne og 1970'erne beskrev knap så detaljeret togrejsen som respondenterne fra den tidligere periode. De har dog alle været med toget til Danmark, og enkelte nævner også, at de sang danske sange på rejsen.

\section{Mad nok til alle}

Ankommet til de respektive byer overalt i Danmark blev feriebørnene afhentet ved toget af deres værtsfamilier, og så kunne opholdet begynde. Størstedelen af undersøgelsens sydslesvigske børn kom fra 1949 til 1974 på ophold i Jylland, men også Fyn og Sjælland var godt besøgt. Nogle kom sågar til Bornholm.

De feriebørn, som var afsted sidst i 1940'erne og i starten af 1950'erne, har beskrevet, at noget af det bedste ved Danmark var maden. Ispinden var, som tidligere nævnt, et nyt og spændende fænomen, men det, at der var mad nok til alle og ingen begrænsninger med hensyn til, hvor meget de måtte få, står også tydeligt frem i erindringerne. Overordnet gav opholdene feriebørnene rigtig mange gode oplevelser, og de oplevede at blive modtaget af glade og venlige mennesker. Størstedelen af feriebørnene beskrev, at de blev en del af de danske familier og oplevede familiehyggen i de danske hjem.

En stor gevinst for feriebørnene var det også at få nye kammerater Det var de nye brødre eller søstre, som fulgte med familierne, eller også var det nabobørn, som blev feriebarnets nye legekammerater. Nogle af disse relationer havde holdt ved $\mathrm{i}$ årevis og løb derefter stille og roligt ud i sandet, mens andre stadig opretholdt kontakten med deres ferievenner.

En bil var ikke hvermandseje i Sydslesvig i 1950'erne og da slet ikke for de arbejderfamilier, som i stort omfang sendte deres børn på ferie i Danmark. Det var derfor en stor glæde for nogle af feriebørnene, når deres danske værtsfamilier havde en sådan. Bilen gav dem gode oplevelser og mulighed for at se mere af Danmark end det nærmeste nabolag. Flere af dem husker endda bilens mærke, så det har øjensynligt gjort et stort indtryk på dem at komme til et hjem med bil. Spændende var det også for de børn, der kom fra Flensborgs bymiljø, at komme til en gård i Danmark med alt, hvad dertil hørte. Landlivet i Danmark var meget anderledes end det liv, de kendte til hjemmefra, og mange har berettet om kontakten med dyrene, såsom heste, grise, køer og kattekillinger, som de fik lov at snakke med. De deltog også i de daglige gøremål på gården og var med i høsten, hvilket flere af dem erindrede som en rigtig god oplevelse. Det kan naturligvis godt tænkes, at arbejdet på gårdene fremstår $\mathrm{i}$ et bedre lys i den senere erindring, end det gjorde $\mathrm{i}$ samtiden, men det at værtsfamilierne tog feriebørnene med i de daglige gøremål og derved inddrog dem i familien på lige fod med alle andre, må formodes at have været det positive træk ved oplevelserne. At børnene fik lov til at deltage $i$ arbejdsopgaverne sammen med gårdenes medhjælpere og familiens voksne havde også et andet positivt aspekt, idet de oplevede en anden barn/voksen-relation, end de var vant til hjemmefra. Flere af de tidligere feriebørn har således berettet om en militant og autoritær tone, hvormed de blev mødt af de voksne i Sydslesvig. Samlet kan det konkluderes, at feriebørnenes erindringer fra landbolivet var positive, primært fordi de igennem arbejdet og fællesskabet fik et nært forhold til værtsfamilien og medarbejderne på gården.

Feriebørnene, som var afsted i perioden cirka 1960 til 1974, havde ligeledes gode oplevelser med deres værtsfamilier. Men samtidig ses det også, at der på dette tidspunkt var sket et skred i økonomien for såvel danskerne som sydslesvigerne. Hvor de feriebørn, som var afsted fra sidst i 1940'erne til midt i 1950'erne, havde meget fokus på maden, havde denne senere gruppe feriebørn mere fokus på de mange oplevelser i form af ture til Tivoli, zoologiske haver og lignende. Det viser, at ferieværternes vilkår havde ændret sig, så der nu både var tid og råd til udflugter, men samtidig også, at forholdene i Sydslesvig var blevet forbedret. Der blev ikke længere fortalt om deltagelse i de huslige gøremål, men derimod om hyggelige stunder i familiens skød. Flere feriebørn skildrede, at de følte sig trygge hos deres værtfamilier, og at de blev behandlet ordentligt og godt. De, der i denne periode var afsted som feriebørn på en gård, og det var nu kun en tredjedel mod halvdelen i den tidligere periode, kunne ligesom de tidligere feriebørn fortælle om gode oplevelser på landet. De fik lov til at sidde med i traktoren og til at lege med de forskellige dyr, men man hører ikke på samme måde som i perioden fra 1949 til 1960 om, at de decideret hjalp til på gården.

Der kan konkluderes, at værtsfamilierne på dette tidspunkt har haft mere fritid, hvilket viser sig ved de mange udflugtsmål, som feriebørnene kunne erindre, og at børnene også i denne periode oplevede at blive gjort til en del af familien. 
Ifølge de besvarede spørgeskemaer var det altså primært positive oplevelser, som feriebørnene havde i Danmark. Var der også negative oplevelser, er de tilsyneladende blevet skubbet i baggrunden til fordel for de mere glædelige aspekter. Ét fænomen blev dog angivet som noget negativt hos små 20 \% af de adspurgte, som var afsted i 1940'erne og 1950'erne, og det var hjemve. De, som havde haft hjemve, gav som forklaring, at de havde haft problemer med sproget. Det var derimod kun en meget mindre del af dem, som var afsted i 1960'erne og 1970'erne, der huskede at have oplevet hjemve. Andre oplevelser, som er blevet klassificeret som værende negative, var småskænderier med værtsfamiliens børn og afskeden med familien, da ferieopholdet var slut. Den mest negative oplevelse blev beskrevet af et feriebarn, som var afsted sammen med sin søster. Her var ferieværten kommet for sent, da hun skulle hente pigerne, og dernæst viste det sig, at hun egentlig ikke havde plads til at have nogen boende. Pigerne måtte derfor sove sammen med deres ferievært og en hund i den samme seng. Der var heller ikke købt ind, da de to ankom, og feriebarnet havde fået det indtryk, at værtsmoderen slet ikke havde råd til at have dem boende. På den baggrund havde det tidligere feriebarn ikke siden givet sine egne børn lov til at komme på ferieophold i Danmark. Eksemplet viser, at der også forekom knap så rosenrøde oplevelser, men der foreligger for få af den slags tilkendegivelser til, at der kan udledes noget generelt heraf.

\section{En ny familie}

Størstedelen af de tidligere feriebørn betragtede deres værtfamilie som deres egen familie. Forholdet til værtsfamilien blev beskrevet som værende meget godt af $85 \%$ af respondenterne, og $31 \%$ af de adspurgte fra perioden 1949 til 1960 holdt på besvarelsestidspunktet stadig kontakt med deres tidligere værtsfamilie i form af besøg og telefonopkald. Hertil skal føjes, at andre 28 \% fortalte, at deres værtsfamilie var gået bort, men at de havde haft kontakt med dem indtil da. I perioden 1960 til 1974 kunne det forventes, at et større antal feriebørn holdt kontakten vedlige med deres tidligere værtsfamilie, da perioden jo ikke ligger så langt tilbage i tiden, og færre værtsforældre derfor var døde, nemlig kun $14 \%$. Dette bekræftes også af spørgeskemaundersøgelsen, idet 37 $\%$ fra denne periode stadig havde kontakt med værtsfamilien. Forskellen på 6 procentpoint i forhold til den tidlige periode er dog ikke særlig markant, især ikke når man erindrer, at der kun indgik 19 respondenter i den sene periode, og at et enkelt svar således tæller godt $5 \%$. I den sene periode var der i øvrigt også procentvis flere, som svarede nej til, at de holdt kontakt (48\%) end i den tidlige periode (40\%).

Til de fleste værtsfamilier hørte også børn, nemlig $87 \%$ i perioden 1949 til 1960 og 83 \% i perioden 1960 til 1974. En stor del af feriebørnene fra begge perioder betragtede disse børn som søskende, og der forekom i begge perioder eksempler på, hvordan feriebørnene og værtsfamiliens børn havde et almindeligt søskende forhold på både godt og ondt. Feriebørnene skændtes med deres feriesøskende, men elskede alligevel at være sammen med dem og ville ikke være dem foruden. Generelt for begge perioder viste det sig, at feriebørnene havde et familiært forhold til deres værtsfamilier og derigennem oplevede en dansk form for hygge og samhørighed, som ikke alle oplevede at kunne få på samme måde med de voksne i Sydslesvig.

\section{Hvad var forskellene?}

Skønt kun en grænse skilte Danmark og Tyskland, mærkede feriebørnene en betydelig forskel på Danmark og Sydslesvig. De børn, som var afsted lige efter Anden Verdenskrig, noterede sig, at Danmark ikke var mærket af krigen, sådan som Sydslesvig var det. Flere har således berettet om deres hjemlige forhold, der var præget af de mange flygtninge og den deraf opståede store boligmangel. De oplevede også en del kriminalitet i Sydslesvig efter krigen, så feriebørnene følte sig mere trygge og frie i Danmark. Det blev også nævnt, at de voksne i Danmark havde mere overskud til børnene, hvorimod nogle af feriebørnene følte, at forældrene i Sydslesvig var udkørte, og at der herskede en dårlig stemning i hjemmet. Forholdet mellem børn og voksne var også mere afslappet i Danmark end i Sydslesvig. Det afslappede forhold kom i Danmark blandt andet til udtryk i, at man her sagde ' $d u^{\prime}$ til hinanden og ikke 'De' som syd for grænsen. Danmark blev således generelt beskrevet positivt af feriebørnene fra perioden 1949 til 1960.

Når der blev spurgt til forskellene mellem Danmark og Sydslesvig, satte efterkrigstidens feriebørn igen fokus på maden, for i Danmark var der rigeligt med mad modsat i Sydslesvig, hvor mange havde oplevet sult. Feriebørnene oplevede danskerne som rige, fordi de tilsyneladende kunne købe nærmest alt, hvad de havde brug for og lyst til. Feriebørnene kom med halvtomme kufferter og returnerede med nye garderober og mad til familien syd for grænsen. 


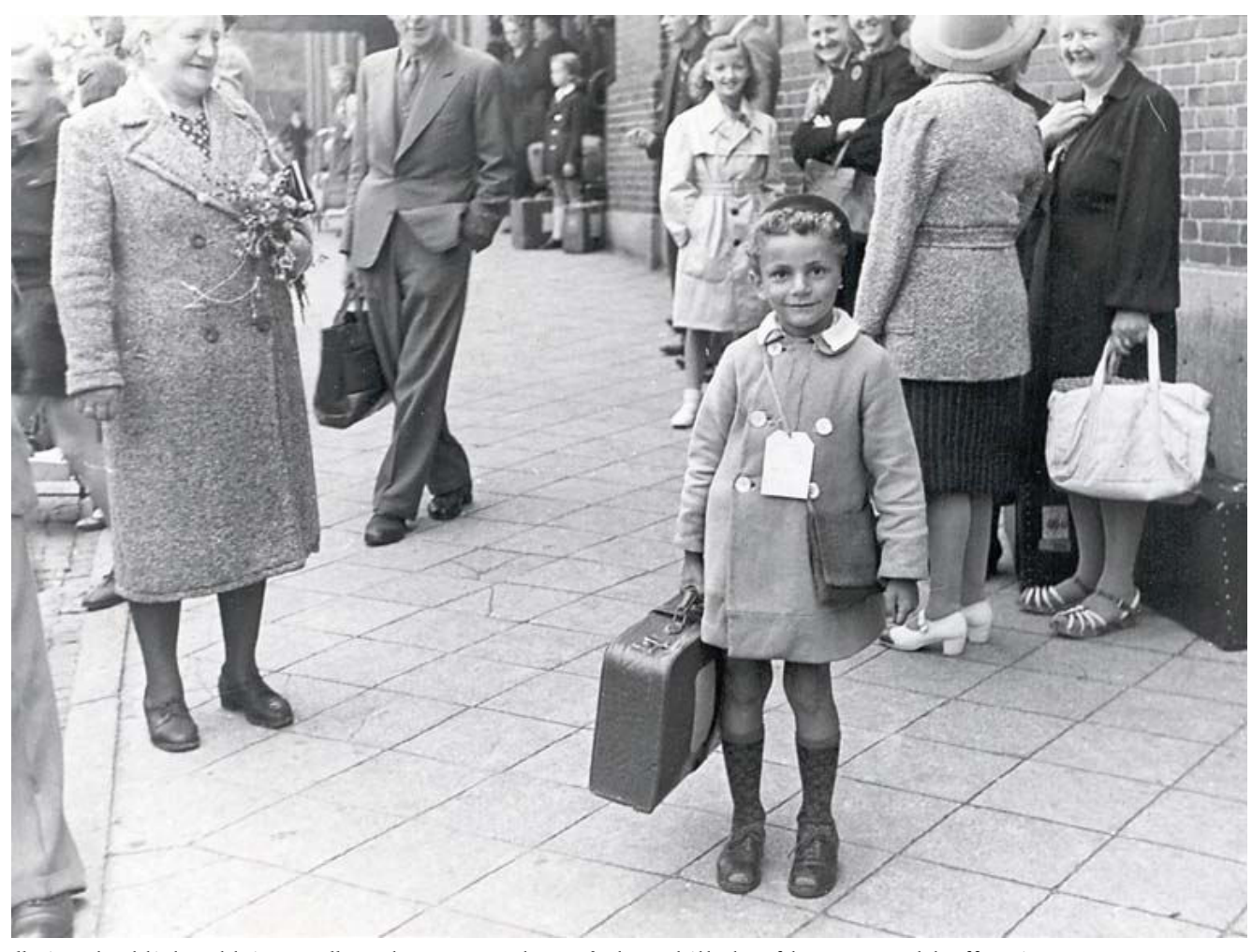

"Ein glücklicher kleiner..." er der noteret bag på dette billede af barnet med kuffert hånden og rejsepas om halsen på Flensborg Banegård 1949. Kilde: Arkivet ved Dansk Centralbibliotek for Sydslesvig, fotograf Hannemann.

Feriebørnene i perioden 1960 til 1974 havde også noteret sig forskelle på hjemme og ude. Her var det især kulturen og tolerancen, som var anderledes i Danmark end i Sydslesvig. Danmark blev også her beskrevet som hyggeligere og et godt sted at være. Opdragelsen af og forståelsen for unge mennesker var ligeledes anderledes og mere fri i Danmark end hjemme i Sydslesvig. I Danmark var børn velkomne, når forældrene havde gæster eller var til fest om aftenen. Det var ikke tilfældet i Tyskland. Der var også forskel på, hvornår man fik kærester og måtte ryge. Der var generelt en mere fri tilværelse i Danmark, og der sås heller ikke den samme respekt for autoriteter som i Sydslesvig.

Fælles for de to perioder gælder, at feriebørnene syntes, der var stor forskel mellem de to kulturer og mentaliteter, hvor Danmark efterlod et skær af en mere fri og afslappet tilgang til tingene. Faktisk var den generelle beskrivelse af Danmark så positiv, at det næsten virker overdrevent forherligende.

\section{På den korte og den lange bane}

På den korte bane fik de sydslesvigske børn en kæmpe oplevelse ved at komme til Danmark på ferie på egen hånd. De fik indsigt i den danske kultur og tog en del af den danske identitet med sig tilbage. De knyttede samtidig nogle familiære bånd med deres værtsfamilier, som mange af dem ikke kun fik glæde af på kort sigt, men også langt ud i fremtiden. For nogle af feriebørnene fra den tidlige periode lige efter Anden Verdenskrig fik værtsfamilien formodentlig en særlig stor betydning, idet det fremgik af spørgeskemaerne, at $34 \%$ af børnene havde mistet deres far, heraf knap en femtedel som følge af krigen.

På både kort og lang sigt fik de alle desuden en sproglig fordel, da de ved udelukkende at tale dansk en hel sommer fik det indlært, så de efterfølgende kunne tale sproget flydende.

På den lange bane fik de tidligere feriebørn forskellige former for udbytte ud af at have været på ferieophold i Danmark. $46 \%$ af dem, som var afsted i perioden 1949 til 1960, mente således, at opholdet havde haft indvirkning på deres senere valg af erhverv. I perioden 1960 til 1974 gjaldt dette for $32 \%$. For den tidlige periodes vedkommende valgte flere af dem erhvervsretninger, hvor de kunne udnytte deres danske sprogkundskaber. Sprogkundskaberne gav dem også en fordel i forhold til at studere. De havde både mulighed for at læse i Tyskland, men også i Danmark, hvilket der var flere, som valgte at gøre. Andre valgte at blive en del af det danske mindretalsarbejde i Sydslesvig gennem ansættelse i foreningslivet og de danske skoler. Af de $32 \%$ af feriebørnene fra den senere periode, som skrev, at opholdet havde haft indvirkning på deres senere karriere, havde en stor del af dem haft arbejde i Danmark. Nogle af dem blev inspirerede af deres værtsforældre til at tage bestemte uddannelser, i øvrigt ligesom nogle af feriebørnene fra den tidligere periode. I denne periode var der også tidligere feriebørn, som fik arbejde ved de danske skoler i Flensborg efter opholdet i Danmark.

Foruden de arbejdsrelaterede effekter af opholdet i Danmark berettede næsten alle de tidligere feriebørn fra 1949 til 1960, at de også tog noget andet med sig fra ferieopholdene ind i deres videre liv. En betydelig del af dem fortalte, at opholdene havde givet dem nogle andre menne- 
skelige kvaliteter, blandt andet et mere åbent og tolerant menneskesyn, ligesom de også havde overtaget danske skikke og væremåder. Nogen af feriebørnene tog den danske mentalitet og den danske væremåde så meget til sig, så de efterfølgende følte sig mere danske end tyske. Flere meddelte, at de siden følte sig mere hjemme i Danmark, og at landet også var deres land. Generelt beskrev de tidligere feriebørn fra efterkrigstiden, at deres ophold i Danmark gav dem indsigt i en anderledes levemåde og en anden form for familieliv, end de var vant til.

Noget lignende gjaldt feriebørnene fra perioden 1960 til 1974. Det, som de fleste omtalte, var nogen særlige menneskelige egenskaber. Her blev der blandt andet talt om en dansk mentalitet og en dansk væremåde. Andre fortalte, at de fra Danmark havde fået en forståelse for en anden kultur, en sproglig fordel og et realistisk billede af landet.

En lille del af feriebørnene fra perioden 1960 til 1974 beskrev, hvordan deres ophold i Danmark gjorde, at de fik lyst til at bosætte sig i landet. Og det er interessant at se, at over halvdelen af feriebørnene fra denne periode faktisk var bosiddende i Danmark, da de besvarede spørgeskemaet. Cirka en tredjedel af feriebørnene fra 1949 til 1960 valgte også at bosætte sig i Danmark senere i livet.

Man kan konkludere, at opholdene især gav feriebørnene en indsigt i en anderledes levemåde og kultur og dermed nogle nye menneskelige værdier. De gav dem samtidig en sproglig fordel i såvel arbejdsmæssig som studiemæssig henseende.

\section{At være ferievært}

De, som blev ferieværter for et sydslesvigsk barn i den samlede periode, gjorde det blandt andet for at hjælpe et barn fra det danske mindretal syd for grænsen. Men de sydslesvigske børn kunne også være tænkt som legekammerater for familiernes egne børn. Nogle af opholdene startede under eller lige efter Anden Verdenskrig, hvor familierne gerne ville være med til at hjælpe de underernærede og nødlidende mindretalsbørn rent humanitært. Andre var nationalt engageret i den danske bevægelse syd for grænsen, og mange havde en almindelig interesse i grænselandet og det danske mindretal.

Cirka halvdelen af de adspurgte erindrede, at de for at blive godkendt som værtsfamilie havde haft besøg af et medlem af Sydslesvigsk Forening eller en af de dertil hørende lokalforeninger. Den anden halvdel angav, at de ikke blev godkendt som værtfamilie, men at alle var glade, når der blev åbnet et hjem for børnene. Socialministeriet udsendte i 1966 et "Cirkulære om tilladelse til og tilsyn med privat familiepleje"12, så det formodes derfor, at der efter 1966 har været en vis form for opsyn med, hvem der blev ferieværter. Fra Sydslesvig foregik formidlingen af kontakten mellem feriebarn og værtsfamilie via en sammenslutning mellem Grænseforeningen, Skoleforeningen og Sydslesvigske børns Ferierejser. Nogle skoler i Sydslesvig havde en form for venskabsforbindelse med en dansk skole, og så blev det bestemmende for, hvor feriebørnene kom hen.

Værterne erindrede mange gode oplevelser med feriebørnene. De, som på daværende tidspunkt var bosiddende på en gård, kunne huske, at feriebarnet hjalp til med de obligatoriske gøremål inden for landbruget og hyggede sig med det. Andre værter berettede om oplevelser med besøg i sommerhus, kortspil og badning i havet, hvilket ligeledes var en succes.

Generelt angav værtsfamilierne, at de feriebørn, som de havde på besøg, var nemme at have boende, idet de hurtigt faldt til i familien. Der var ingen, som beskrev dårlige oplevelser med feriebørnene udover små bagateller. Her skal det igen påpeges, at de 19 besvarelser ikke har været nok til at skabe et repræsentativt felt af værtsfamilier. Nogle værtsfamilier må forventes at have haft dårlige oplevelser med et feriebarn, men har enten ikke hørt om undersøgelsen eller valgt ikke at deltage. De hjertelige og gode forhold mellem tidligere værter og feriebørn ses også i nogle julekort fra Danmark, som et par af respondenterne havde gemt og venligst udlånte i forbindelse med undersøgelsen. Her kan man læse, hvordan feriebørnene var savnet hos værtsfamilierne, og at der blev sendt julepakker fra Danmark til Sydslesvig.

En stor del af de deltagende værtsfamilier fik indsigt i den sydslesvigske kultur ved at have et sydslesvigsk barn boende. Nogle oplyste at have fået kendskab til skolegangen i de danske skoler syd for grænsen og fik sat ord på, hvordan det var at leve som et mindretal i et andet land. Cirka halvdelen af værterne fik et indblik i, hvor fattigt det havde været i Sydslesvig efter Anden Verdenskrig.

Værternes familiære forhold til feriebørnene fortsatte efter, at feriebørnene var rejst hjem til Sydslesvig. Cirka $90 \%$ af værterne holdt således kontakten ved lige med deres feriebarn, efter at barnet var rejst hjem. Små 85 \% havde stadigvæk kontakt med hinanden, primært ved hjælp af telefonopkald og besøg.

Ordningen med feriebørnene ophørte, da børnene forlod skolen. Dertil skal dog siges, at undersøgelsens feriebørn, i hvert fald i de fleste 
tilfælde, forsatte med at komme hos deres værtsfamilier. Nogle valgte endda at cykle til Danmark for at være sammen med værtsfamilien. Andre valgte som tidligere nævnt at få et arbejde i Danmark.

Generelt viste der sig et positivt billede af livet som værtsfamilie. Der blev skabt nogle familiære bånd, som rakte langt ind i fremtiden, og mange af dem bestod stadigvæk, da spørgeskemaet blev udfyldt. Værtsfamilierne fik en ekstra familie syd for grænsen, som gav dem indblik i livet som nationalt mindretal i et andet land. De havde samtidig været med til at styrke den danske identitet i Sydslesvig ved at videregive nogle danske værdier og en dansk kultur til deres feriebørn. Dog er det som nævnt vigtigt at have for øje, at der kun var 19 respondenter i denne gruppe, og at de ydermere var aldrende. Oplevelserne med feriebørnene lå langt tilbage, og selvom de havde haft mere end et feriebarn boende, var det særligt den ene, som de stadig havde kontakt med, som de skrev om.

\section{Afrunding}

Spørgeskemaundersøgelsen af de sydslesvigske børns ferierejser til Danmark fra 1949 til 1974 gav et indblik i, hvordan et ferieophold i Danmark blev erindret af de deltagende. Deres tilbageblik på oplevelserne viste sig at være ganske positive. Der hersker ingen tvivl om, at et sådant ophold gjorde indtryk på et barn, som var afsted uden sine forældre i en tidlig alder. Jeg er efterfølgende blevet belært om, at værtsforældre, som jeg har kaldt dem, ikke er den korrekte betegnelse, men at de af feriebørnene blev benævnt "plejeforældre", hvilket siger noget om, hvor tætte bånd der blev knyttet under opholdene. Og det giver god mening, når man tager i betragtning, at det både var børn i børnehavealderen og i skolealderen, som kom til Danmark.

Feriebørnene er et specielt emne at arbejde med, og hver gang jeg har mødt tidligere feriebørn, har de kunnet tilslutte sig nogle af undersøgelsens aspekter og samtidig komme med yderligere oplysninger om deres ophold. Der er andre dele af ferierejsernes historie, som endnu ikke er afdækket, og samtidig også en lang årrække, der kan forskes i. Jeg valgte at fokusere på den menneskelige og emotionelle del af ferierejserne i stedet for den organisatoriske del.

Undersøgelsen har vist, at der er generelle forhold, som går igen på rejserne, men også at feriebørnene fik individuelle værdier med retur.
Kunne man få et endnu større antal tidligere feriebørn til at deltage i en lignende undersøgelse, ville resultaterne givetvis blive mere præcise, men denne undersøgelse har dog været med til at give et indblik $i$ en vigtig del af mindretallets historie.
KILDER

Utrykte kilder: vig $(A D C B)$ :

F 233-1 Komiteen for slesvigske/sydslesvigske børns ferierejser, Forhandlingsprotokol og breve 1949-2001.

\section{LITTERATUR}

Feldbæk, Ole (red.): Dansk Identitetshistorie 4: Danmark og Europa 1940-1990, Кøbenhavn 1992.

Jensen, Marianne Brink: Sydslesvigske børns ferierejser til Danmark 1949-1974 speciale ved SDU 2016. (Et eksemplar Sydslesvig, Flensborg).

Johannsen, Per og Hanne Midskov: "85 år med sydslesvigske feriebørn", Grænseforeningens årbog 2004, s. 11-27.

Klatt, Martin: "Genforening eller mindretal 1945-1955", Lars N. Henningsen (red.): Sydslesvigs danske historie, Flensborg 2013, s. 177-236.

\section{NOTER}

1 René Rasmussen 2013, s. 118

2 Johannsen og Midskov 2004, s. 12-16.

Johannsen og Midskov 2004, s. 16-17. sydslesvigske-borns-ferierejser.ht

6 Martin Klatt 2013, s. 205.
Arkivet ved Dansk Centralbibliotek i Sydslesfindes på Dansk Centralbibliotek for http:// www.graenseforeningen.dk/
F233-7 Komiteen for slesvigske/sydslesvigske børns ferierejser, Landskomitémøder og historiesamlinger 1998-2008. Arkivet ved Dansk Skoleforening Flensborg (ADSF),

Ferierejser 1966-1971, 1948-1979.
Lange, Ulrich: Geschichte Schleswig-Holsteins: Von den Anfängen bis zur Gegenwart, Neumünster 1996.

Noack, Johan Peter: Det sydslesvigske grænsespørgsmål 1945-1947, bd. 1, Aabenraa 1991.

Rasmussen, René: "Under Preussen 1864-1945", Lars N. Henningsen (red.): Sydslesvigs danske historie, Flensborg 2013, s. 47-176.

Sydslesvigsk Forening: Sydslesvig i tekst og tal, Flensborg 1988 .

7 ADCB F 233-1, 5 og F233-7,

8 Johannsen og Midskov 2004, s. 20-21. ADSF, Ferierejser 1972-74, 1948-1979. 10 ADSF, 1948-1966, 1948-1979.

11 Johannsen og Midskov 2004, s. 19 


\section{Zusammenfassung}

Im Jahr 1919 begann die Regelung mit den Ferienkindern, wo Kinder aus Südschleswig ihre Schulferien bei dänischen Familien verbringen konnten.

In diesem Artikel wird über Ferienkinder berichtet, die im Zeitraum 1949-1974 aus Südschleswig nach Dänemark kamen. Im Jahr 2016 machte ich eine Befragung, die das Erlebnis der Ferienkinder und die Bedeutung ihres Aufenthaltes auf längere und kürzere Sicht untersuchen sollte. Dieser Artikel nimmt in der Untersuchung seinen Ausgangspunkt.

Die Ferienkinder gehörten der dänischen Minderheit in Südschleswig an, sie besuchten alle die dänische Schule und den dänischen Kindergarten. Die Ferienreisen nach Dänemark waren für sie ein Erlebnis fürs Leben mit sprachlichen Gewinnen und mit einer neuen Familie nördlich der Grenze. Viele der Ferienkinder wohnten bei ihren dänischen Wirtsfamilien mehrere Jahre nacheinander. Nachdem sie die Schule verlassen hatten, besuchten sie selbst die Ferienfamilien und bei vielen von ihnen wurde die Verbindung mit Besuchen und Telefonaten aufrecht erhalten.

Die Gründe für einen Ferienaufenthalt in den 1940'er und 1950'er Jahren unterschieden sich von denen der 1960'er und 1970'er. Die Ferienkinder der ersten Periode reisten nach Dänemark, u.a. weil sie nach dem Zweiten Weltkrieg unterernährt waren und gutes Essen und Fürsorge benötigten. Die Kinder im späteren Zeitraum reisten, weil es für die Familie zur Tradition geworden war und um ihre sprachlichen Fähigkeiten zu verbessern. Gemeinsam für alle war es, einen Teil dänischer Mentalität mit sich nach Hause zu nehmen und einen Einblick in das Familienleben der Dänen zu bekommen.

\section{Anmeldelser}

\section{Bramming, Torben: Rantzau. Den hellige kriger}

Kristelig Dagblads Forlag, Viborg 2016, 290 s.

Når man ser bort fra fyrsternes rækker, er adelsmanden Johann Rantzau til Breitenburg den mest betydelige slesvig-holstenske personlighed på reformationstiden. Først sikrede han Frederik 1.s kongemagt, da han slog Christian 2.s tro mand, Søren Nordby, på slagmarken i Skåne i 1525. Dernæst vandt han Grevens Fejde 1534-1536 og banede dermed vejen for indsættelsen af Christian 3. som konge af Danmark. Endelig stod han i spidsen for de slesvig-holstenske hertugers erobring af bonderepublikken Ditmarsken i 1559. Blandt disse hertuger var den danske kong Frederik 2. Johann Rantzau var således en suveræn feltherre og en kongemager uden lige i Danmarkshistorien. Derudover grundlagde han et dynasti, der i de følgende ca. to århundreder blev Slesvig-Holstens førende adelsslægt, ja den blev sågar ophøjet til fyrsteværdighed.

Der har manglet en biografi om Johann Rantzau, og det var derfor med stor spænding og nysgerrighed, at denne anmelder modtog bogen: Får vi nu endelig den samlede historiske analyse af Johann Rantzaus levned, der på grundlag af det samlede bevarede kildemateriale giver en kvalificeret skildring af hans liv og politiske karriere? Desværre nej. Torben Bramming skriver gennemgående godt og engageret, men han kommer aldrig i dybden med sin hovedperson. Vi hører alt for meget om generelle emner i tiden (såsom lejesoldater, kongerne Christian 2. og Christian 3. og reformationen) og alt for lidt om Johann Rantzau. Forfatteren har simpelthen ikke det tilstrækkelige kendskab til Hertugdømmernes historie i almindelighed og et i denne sammenhæng uomgængeligt fænomen som det slesvig-holstenske ridderskab i særdeleshed. Skimmer man litteraturlisten, ser man også hurtigt, at der mangler væsentlige værker. Eksempelvis burde Bramming have orienteret sig i Kai Fuhrmanns værk om det slesvig-holstenske ridderskab og de relevante sider i bind 1 af "den nye" Sønderjyllands Historie fra 2008. I al beskedenhed kunne et kig i min egen bog Fyrste og folk. Hertug Hans den Ældres fyrstestat i 1500-tallets Slesvig-Holsten, Flensborg 2010, også have afværget en række misforståelser.

Den manglende viden fører til adskillige helt banale fejl. Her skal blot nævnes et par af de mest iøjnefaldende. På side 220 får vi at vide, at Johann Rantzaus søn, Henrik Rantzau, fik en forlening i 1537. Han var da omkring 11 år gammel, og det er naturligvis en anden Henrik Rantzau, der er tale om. Langt værre bliver det på siderne 248-249. Her hævdes det, at Christi- 